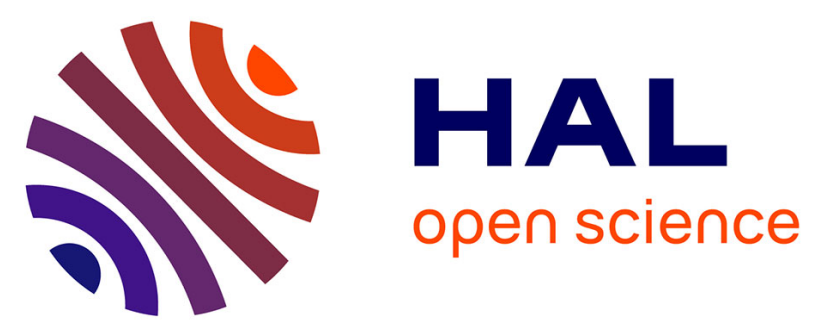

\title{
Faults modeling of the impedance and reversed polarity types within the PV generator operation
}

\author{
Wail Rezgui, Nadia Kinza Mouss, Leilla-Hayet Mouss, Mohamed Djamel \\ Mouss, Yassine Amirat, Mohamed Benbouzid
}

\section{- To cite this version:}

Wail Rezgui, Nadia Kinza Mouss, Leïla-Hayet Mouss, Mohamed Djamel Mouss, Yassine Amirat, et al.. Faults modeling of the impedance and reversed polarity types within the PV generator operation. 2014 IEEE EFEA, Nov 2014, Paris, France. pp.1-6, 10.1109/EFEA.2014.7059979 . hal-01154200

\author{
HAL Id: hal-01154200 \\ https://hal.science/hal-01154200
}

Submitted on 21 May 2015

HAL is a multi-disciplinary open access archive for the deposit and dissemination of scientific research documents, whether they are published or not. The documents may come from teaching and research institutions in France or abroad, or from public or private research centers.
L'archive ouverte pluridisciplinaire HAL, est destinée au dépôt et à la diffusion de documents scientifiques de niveau recherche, publiés ou non, émanant des établissements d'enseignement et de recherche français ou étrangers, des laboratoires publics ou privés. 


\title{
Faults Modeling of the Impedance and Reversed Polarity Types within the PV Generator Operation
}

\author{
Wail Rezgui ${ }^{1}$, Nadia Kinza Mouss ${ }^{1}$, Leïla-Hayet Mouss ${ }^{1}$, \\ Mohamed Djamel Mouss ${ }^{1}$, Yassine Amirat ${ }^{2}$ and Mohamed Benbouzid ${ }^{3}$ \\ ${ }^{1}$ LAP-lab, University of Batna, Batna, Algeria \\ Email: r-wail@hotmail.fr, kinzmouss@yahoo.fr, hayet_mouss@yahoo.fr, d_mouss@yahoo.fr \\ ${ }^{2}$ ISEN Brest, EA 4324 LBMS, Brest, France \\ Email: Yassine.Amirat@isen.fr \\ ${ }^{3}$ University of Brest, EA 4325 LBMS, Brest, France \\ Email: Mohamed.Benbouzid@univ-brest.fr
}

\begin{abstract}
In this paper, we proposed a new mathematical model of the I-V characteristic of a faulty photovoltaic generator. It presents its behavior in normal and faulty operations. In particular, when its basic components such as cells, bypass and blocking diodes are subjected to the impedance or reversed polarity faults.

The developed model of the faulty PV generator will allow studying of the $\mathrm{I}-\mathrm{V}$ characteristic, measures the tolerances of the technical functions, avoids numerous experiments, and ensure better assessment of fault consequences.
\end{abstract}

Index Terms - Photovoltaic Generator; I-V Characteristic; Modeling; Simulation; Impedance and Reversed Polarity Faults.

\section{NOMENCLATURE}

$I_{p h} \quad=$ Photocurrent standard condition.

$I_{0} \quad=$ Reverse saturation current of the diode.

$Z \quad=$ Electrical impedance

$R_{S} \quad=$ Cell series resistance.

$n c: n c g / n c p \quad=$ Cell number: good / defective.

$n g: n g g / n g p \quad=$ Group number: $\operatorname{good} /$ defective.

$n m: n m g / n m p=$ Module number: good / defective.

$n s: n s g / n s p \quad=$ String number: good / defective.

$n f g / n f p \quad=$ Good $/$ defective generator.

$N_{\text {Cells }} \quad=$ Number of cells in each group.

$N_{\text {Groups }} \quad=$ Number of groups in each module.

$N_{\text {Modules }} \quad=$ Number of modules in each string.

$N_{\text {Strings }} \quad=$ Number of strings in each generator.

$V / I \quad=$ Voltage / current.

$P \quad=$ Power.

$I_{\text {Bypass_Diode }} \quad=$ Bypass diode current.

$V_{\text {Cell_Imposed }} \quad=$ Voltage imposed.

$a \quad=$ Diode ideality factor.

$V_{t} \quad=$ Diode Thermal voltage.

\section{INTRODUCTION}

Photovoltaic solar energy represents one type of the three renewable energy categories. It results from the conversion of the solar energy into electrical energy, by a semiconductor material. This conversion assures by the photovoltaic phenomenon, which is discovered by Edmond Becquerel in 1839. This source energy type supports on the world market of production systems energies a very high growth rate around 30 to $40 \%$ per year. This growth lies in its easy usage, its autonomy and its silent and nonpolluting operation.

Photovoltaic generator during its functioning submits to a set of defects, which they decrease its productivity, such as the cells heating, cells crack, degradation and corrosion of the interconnections [3-5]. These defects participate in the appearance of the impedance and the reversed polarity faults, which reduce the power supplies by the faulty generator [6-7]. Modeling the generator behavior in its malfunction, to ensure its availability, facilities its faults detection and diagnosis [1-2].

In this context, the paper objective is the development of a new fault modeling of the PV generator. So, the paper contribution is to propose a new methodology for modeling the photovoltaic generators. This new model bases on his presentation on mathematical equations of the IV characteristic of the faulty basic components: cells, bypass and blocking diodes, which they reformulate by electrical laws. This model presents the faulty behavior of the photovoltaic generator, to quantify the influence degree of these faults on its operation.

\section{MODELING THE PHOTOVOLTAIC GENERATOR IN NORMAL FUNCTIONING}

Modeling the PV generator in the normal functioning can use as a benchmark, to distinguish between normal and abnormal cases, by the results comparison.

Figure1 presents the studied generator. It composes of five parallel strings. Each string contains five modules in series, and terminus with a blocking diode. Each module includes thirty-six cells. These cells distribute on two groups by bypass diodes. In this work, we base the modeling of the photovoltaic cell on the with resistance model. So, the characteristic of a good PV generator is

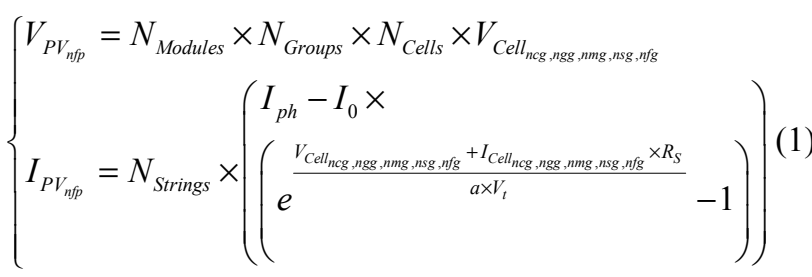




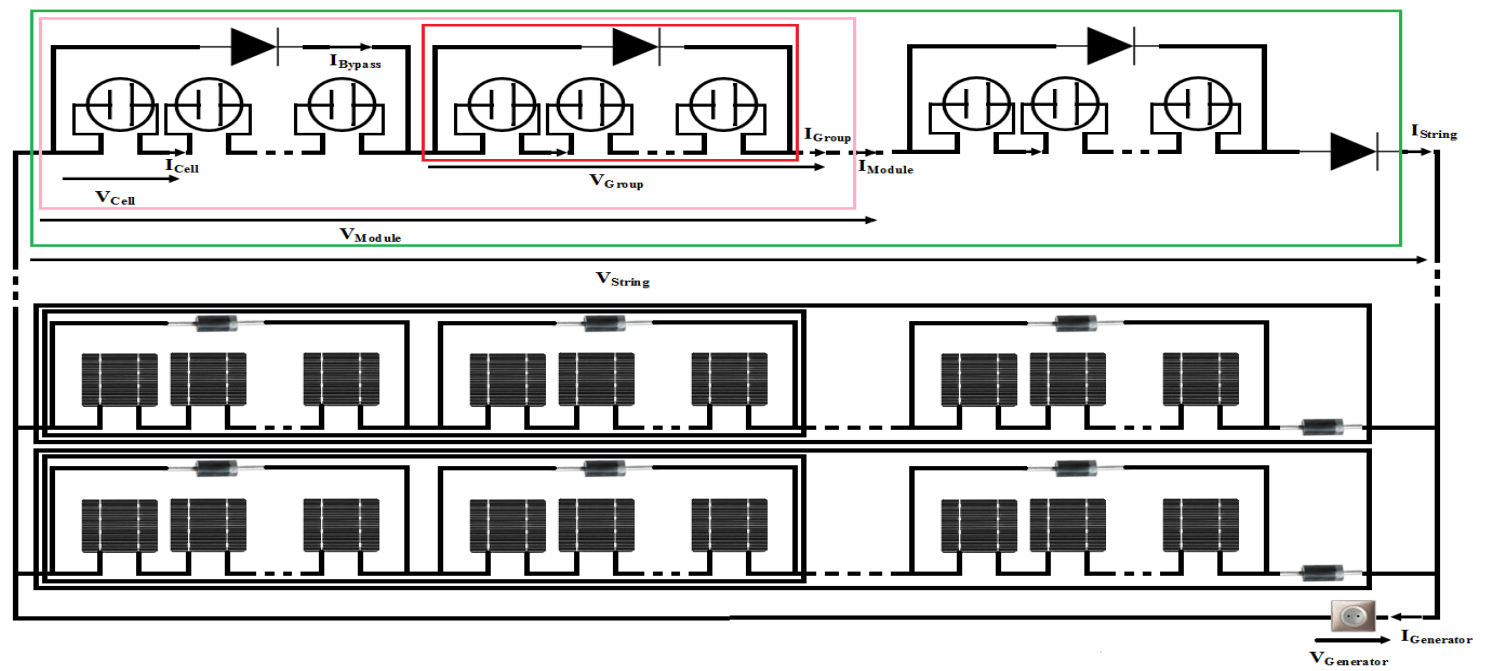

Figure1. Electrical block diagram of a PV generator in its normal functioning

\section{MODELING THE PHOTOVOLTAIC GENERATOR IN MALFUNCTIONING}

\section{A. Defective Cells}

The cell impedance presents the degradation state of the defective cell. Because, practically a simple crack at the cell can increase its resistance. Then, it appears the

cell impedance or heating cell defaults. And finally, it creates the cell open-circuit default, if the cell resistance remains increasing.

$$
\begin{aligned}
& \text { If } \exists \mathrm{nc}=1: \mathrm{N}_{\text {Cells }} \text { of } \exists \mathrm{ng}=1: \mathrm{N}_{\text {Groups' }} \text { of } \exists \mathrm{nm}=1: \mathrm{N}_{\text {Modules }} \text { of } \exists \mathrm{ns}=1: \mathrm{N}_{\text {Strings }} \text {, Icell } \text { nc,ng,nm,ns,nfp } \bullet 0 \\
& \int V_{P V_{n f p}}=\min _{n s=1}^{N_{\text {Strings }}}\left(V_{\text {String }_{n s=n s p, n f p}}\right)
\end{aligned}
$$

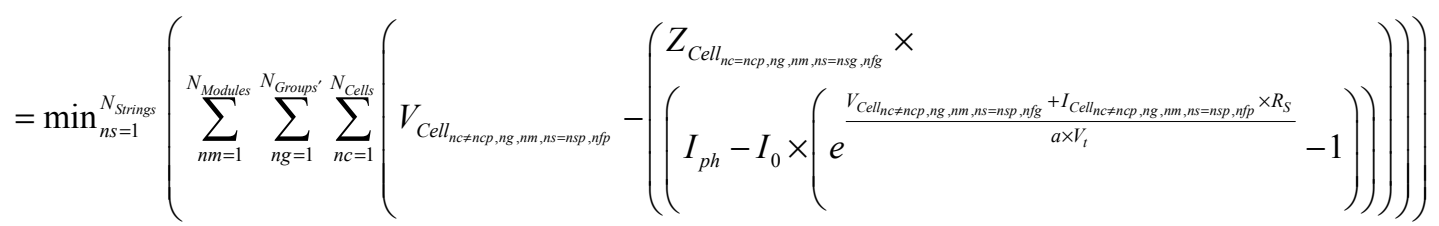

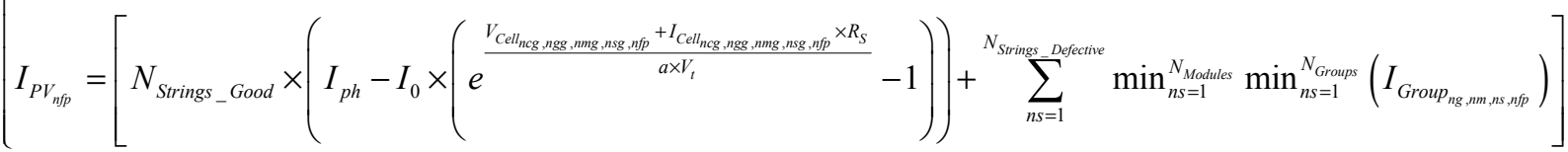

Else

$\left\{\begin{array}{l}V_{P V_{n f p}}=0 \\ I_{P V_{n f p}}=0\end{array}\right.$

End

Where: $N_{\text {Groups }}:$ Number of groups where each one contains at least one good cell.

The second default type is cell reversed polarity. It can provide a negative voltage at its terminals. So, it changes its group operation, which is as a generator, while its voltage is positive, to the short-circuit case when its voltage is null, and finally to a receiver if its voltage is negative.

$$
\begin{aligned}
& \left\{V_{P V_{n f p}}=\min _{n s=1}^{N_{\text {Strings }}}\left(V_{\text {String }_{n s=n s p, n f p}}\right)=\min _{n s=1}^{N_{\text {Strings }}}\left(\sum_{n m=1}^{N_{\text {Modules }}} \sum_{n g=1}^{N_{\text {Groups }}} \sum_{n c=1}^{N_{\text {Cells }}}\left(V_{\text {Cell }_{n c \neq n c p, n g, n n, n s=n s p, n f p}}-V_{\text {Cell }}{ }_{n c=n c p, n g, n m, n s=n s p, n f p}\right)\right)\right. \\
& I_{P V_{n f p}}=\sum_{n s=1}^{N_{\text {Srrings }}} \min _{n m=1}^{N_{\text {Modules }}} \min _{n g=1}^{N_{\text {Groups }}}\left(I_{\text {Group } n g, n m, n s, n f p}\right)
\end{aligned}
$$

\section{B. Defective Bypass Diodes}

Also, among the known defects in the diagnosis of photovoltaic systems: bypass diode impedance. Because, its resistance in the ideal case null. But, its damage increases its resistance, and become remarkable and calculable. The faulty generator characteristic with bypass diode impedance is 


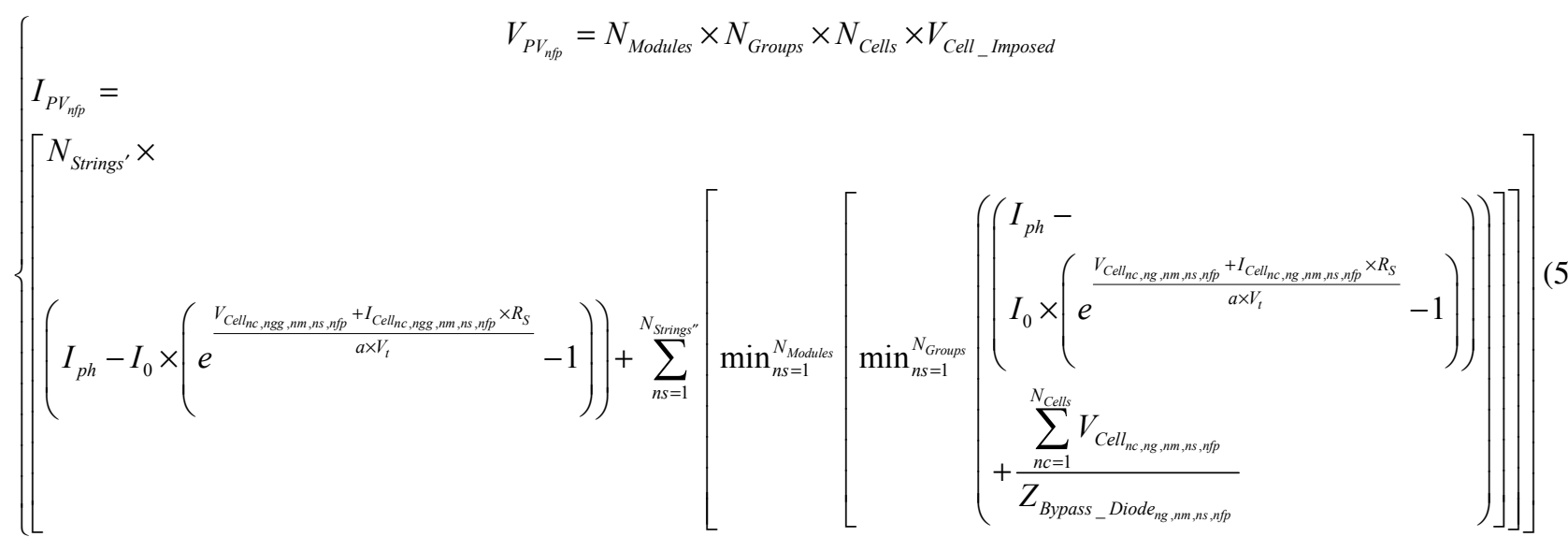

Where: $N_{\text {Srings }}:$ Strings contain at least one good group. $N_{\text {Strings.: }}:$ Strings all its groups are defective.

Secondly, Bypass diode reversed polarity can create short-circuit, which reduces the current of its group, and

cancels outright the voltage provides by the cells grouped by this defective diode.

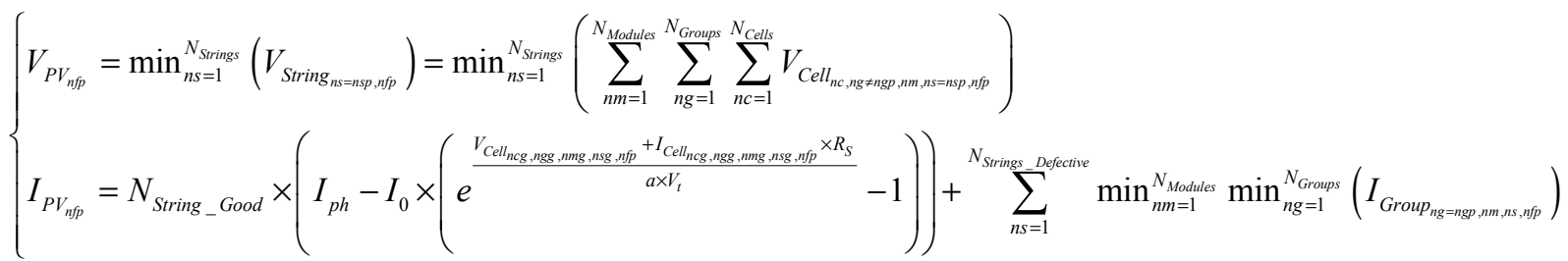

\section{Defective Blocking Diodes}

The blocking diode during its functioning submits to the impedance fault. It changes outright its functioning, and it permits the passage of its current in the both

directions. Also, this defective diode creates a voltage at its terminals, because its resistance increases. The faulty generator characteristic is

If the defective strings cells currents are zero, and its opposite currents are not zero

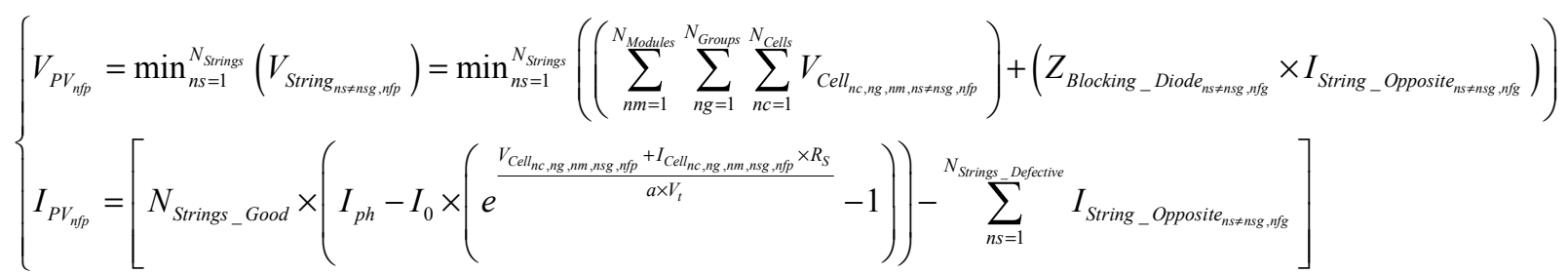

If the defective strings cells currents are not zero, and its opposite currents are zero

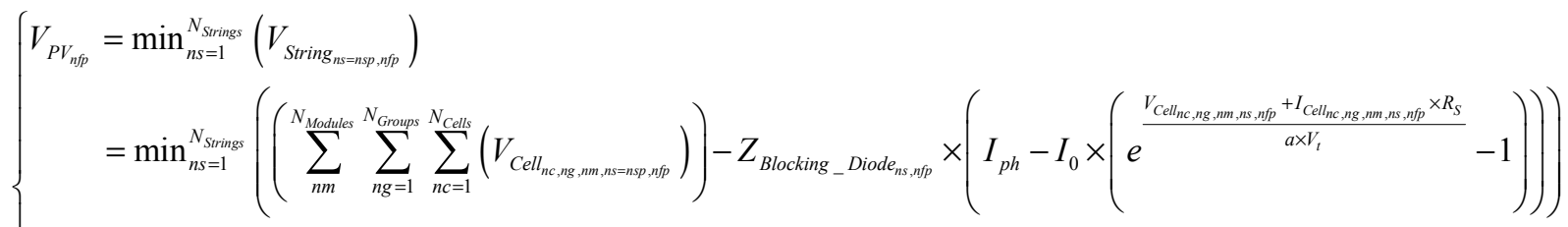

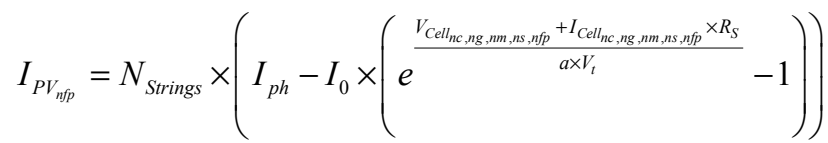

If the defective strings cells currents are not zero, its opposite currents are not zero, and all the generator strings are defective

$$
\left\{\begin{array}{l}
V_{P V_{n f p}}=N_{\text {Modules }} \times N_{\text {Groups }} \times N_{\text {Cells }} \times V_{\text {Cell_open-circuit }} \\
I_{P V_{n f p}}=0
\end{array}\right.
$$

But if this faulty generator contains at least one good string 


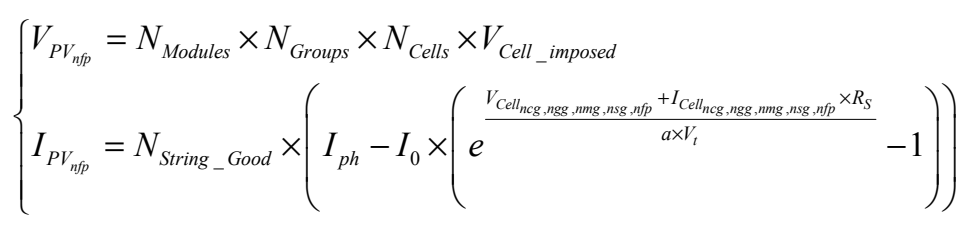

End

A blocking diode reversed polarity reduces the generator productivity. Because, it blocks its faulty string current. And therefore, its string becomes in the open- circuit mode in the presence of its supplied current. Otherwise, its string becomes in the receiver mode.

- If the defective strings cells currents are zero, and its opposite currents are not zero

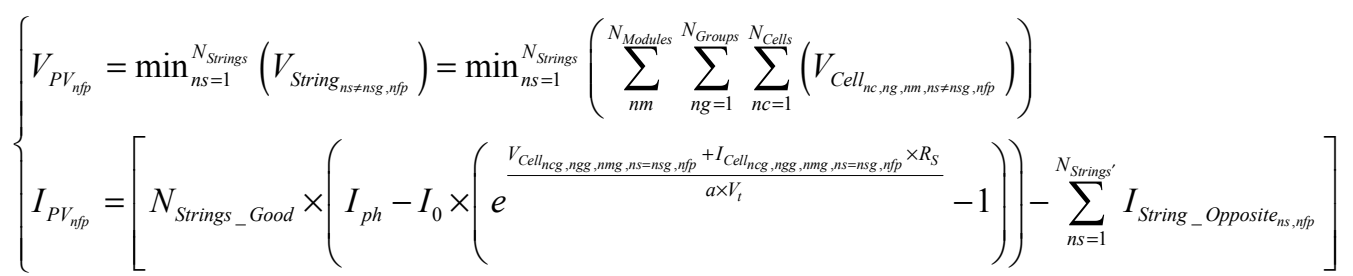

Where $\mathrm{N}_{\text {Strings }}$ : number of defective strings with provided current null.

- If the defective strings cells currents are not zero, its opposite currents are not zero, and all the generator strings are defective

$\left\{\begin{array}{l}V_{P V_{n f p}}=N_{\text {Modules }} \times N_{\text {Groups }} \times N_{\text {Cells }} \times V_{\text {Cell_Open-circuit }} \\ I_{P V_{n f p}}=0\end{array}\right.$

But, if this faulty generator contains at least one good string

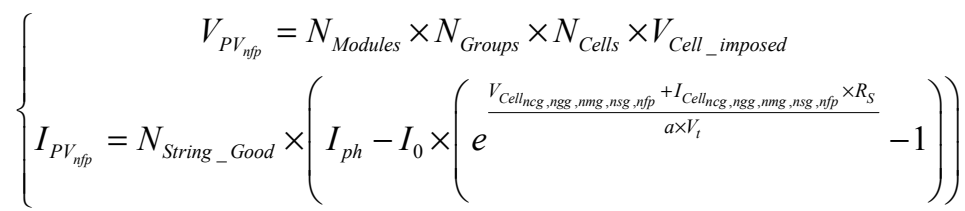

\section{Simulation results}

The results simulations of the PV generator model are shown in the following Figures 2 to 8.

1) Figure 2 shows the IV characteristic and the power of a healthy photovoltaic generator.

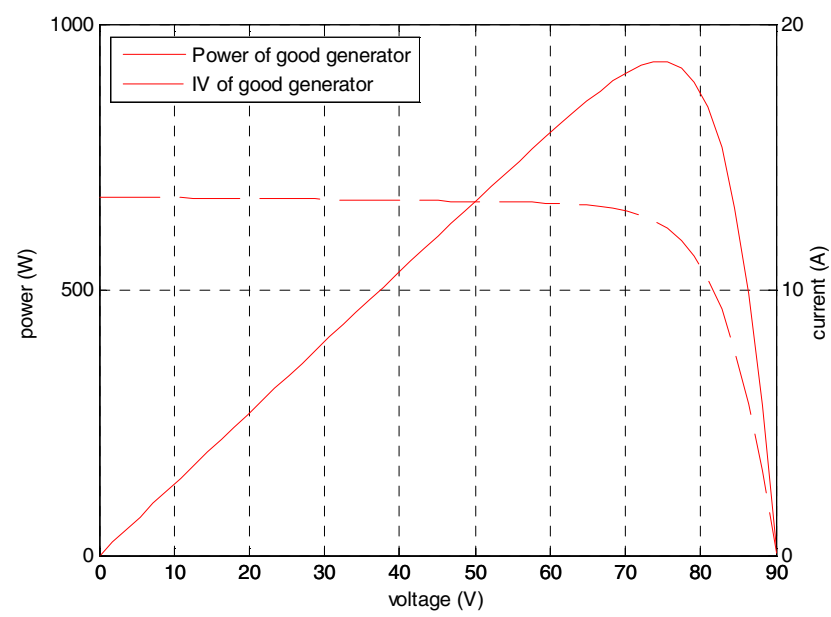

Figure2. I-V \& power of a good PV generator

2) Figure3 presents the functioning of the generator containing cells impedance. It shows that the power of a $\mathrm{PV}$ generator decreases proportional to the number of the defective cells.

3) Figure4 presents the functioning of the generator containing bypass diode impedance. It shows that this defect has no influence on the characterization of a faulty string, which contains at least one good group. Else, the power of the generator increases proportionally to the number of its faulty strings. Because, the currents of these latter increases until reaching its short-circuit values.

4) Figure 5 presents the influence of the blocking diode impedance on the functioning of the PV generator. It shows that this defect makes a significant deterioration in the power generator. Because, it reduces the voltage of its string and it creates the reversed current. The string behaves in a receiver mode if its cells supplied current is null, otherwise it becomes in the open-circuit mode.

5) Figure6 presents the functioning of the generator containing cells reversed polarity. It shows that the power of a PV generator decreases proportional to the number of the defective cells. It reaches the zero value, when the half of the cells is defective. And also, it absorbs more power, if the number of its defective cells greater that the healthy 
ones.

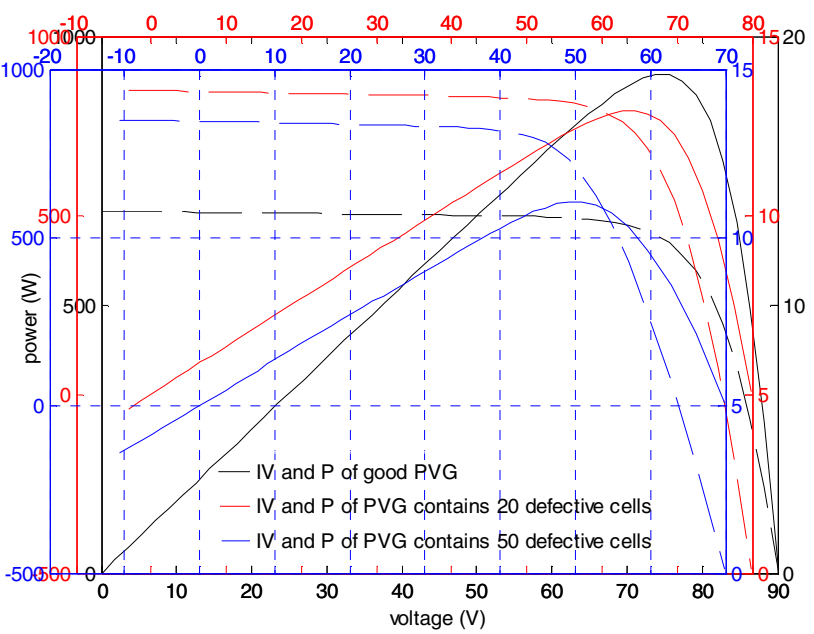

Figure3. IV \& $P$ of the PV contains cells impedance.

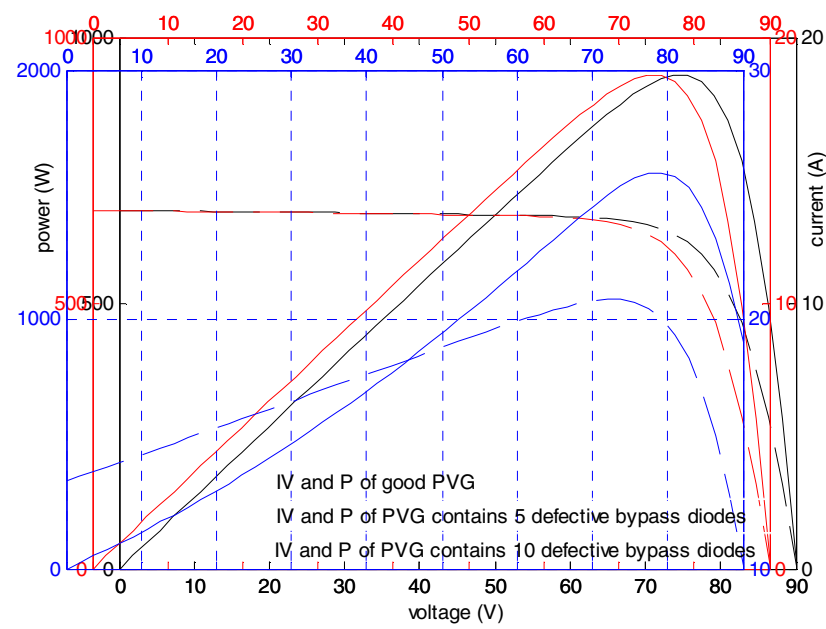

Figure4. IV \& $P$ of the PV contains bypass diode impedance.

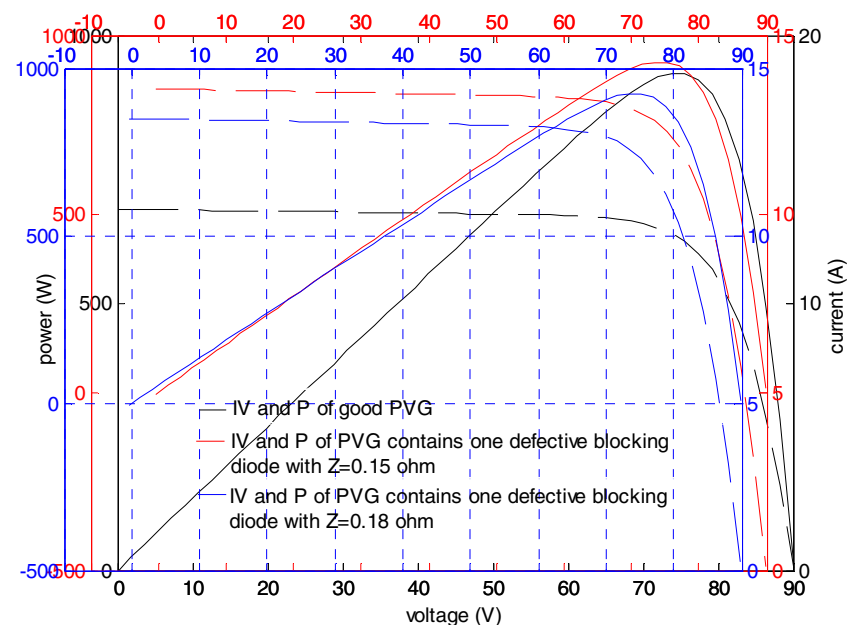

Figure5. IV \& $P$ of the PV contains blocking diode impedance.

6) Figure7 presents the functioning of the generator containing bypass diodes reversed polarity. It shows that this defect has a greater impact on the PV generator performance. Because, it can affects the group voltage. And also it decreases the group current.

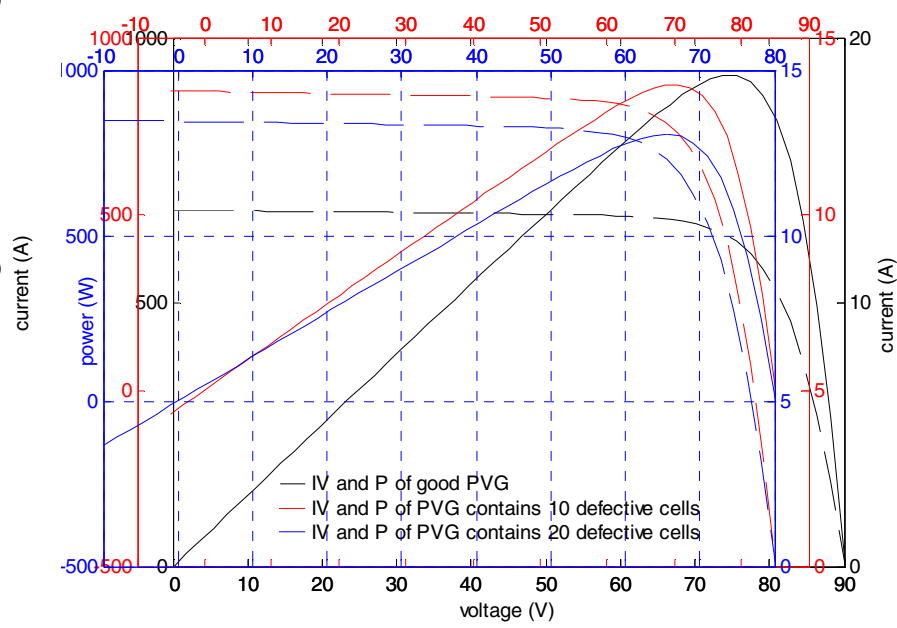

Figure6. IV \& power of PV generator contains cell reversed polarity

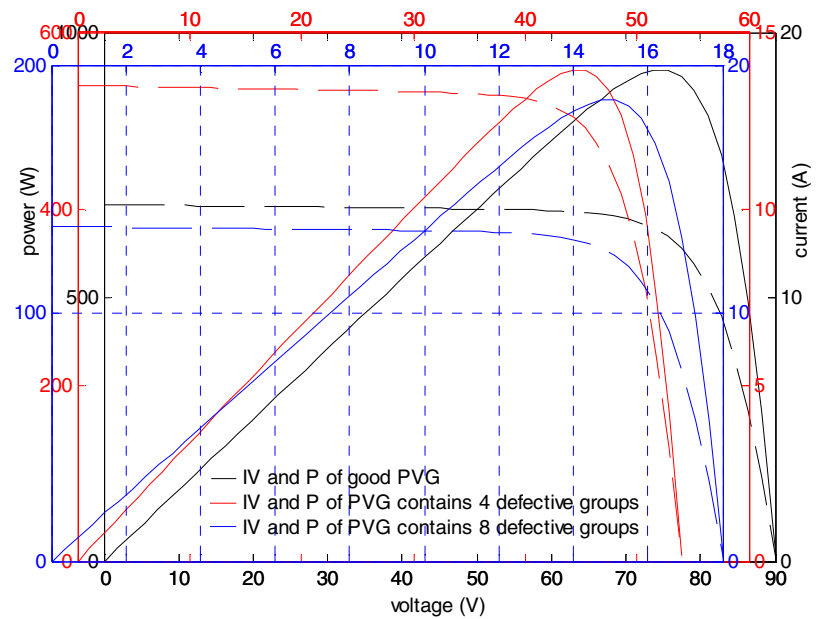

Figure7. IV \& power of PV generator contains bypass diodes reversed polarity

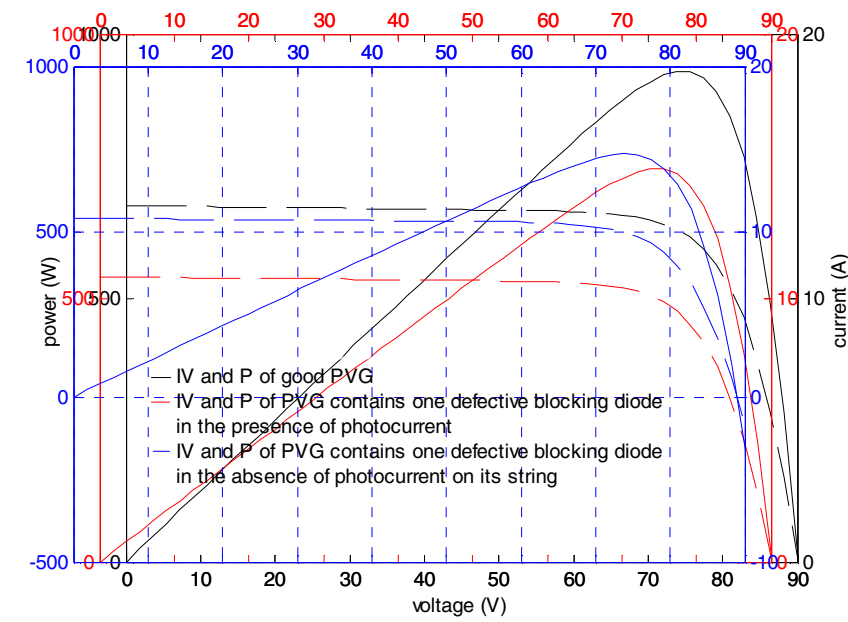

Figure8. IV \& power of PV generator contains blocking diodes reversed polarity

7) Figure 8 presents the functioning of the generator containing blocking diodes reversed polarity. It shows that 
this defect makes a significant deterioration in the generator power. Because, the existence of one defective blocking diode affects the string current flow, and the latter behaves in the open-circuit mode if its cells supplied current is not null. Otherwise, this string becomes in the receiver mode.

\section{CONCLUSION}

This article proposed a new strategy, for the mathematical modeling of the impedance and reversed polarity faults influence, on the IV characteristic and the power of a photovoltaic generator. We concluded that these defects types decrease the generator productivity, either by changing its functioning to the receiver stat, or to the short-circuit stat or also to the open-circuit stat.

The work proposed in this paper, presented the influence modeling of the impedance and reversed polarity faults, on the generator operation, which contained on the most: cells, or bypass diodes, or blocking diodes in impedance or reversed polarity faults. The future work resided in the influence modeling of the impedance and reversed polarity faults, on the generator operation that contained the hybrid of defective cells, bypass diodes and blocking diodes at the same time.

\section{REFERENCES}

[1]. W. Rezgui, L.H. Mouss, M.D Mouss, «Modeling of a photovoltaic field in malfunctioning », in Proceedings of the 2013 IEEE CoDIT (International Conference on Control, Decision and Information Technologies), Hammamet (Tunisia), pp. $788-793$, 6-8 May 2013.

[2]. W. Rezgui, L.H. Mouss, N.K. Mouss, M.D. Mouss, Y. Amirat and M.E.H. Benbouzid, «Electrical faults modeling of the photovoltaic generator», IREMOS (International Review on Modelling and Simulations), Vol.7, ํ2, May 2014.

[3]. L. Dorobantu, M.O. Popescu, C.L. Popescu, «Yield loss of photovoltaic panels caused by depositions ", in the proceeding of 2011 IEEE ATEE ( $7^{\text {th }}$ International Symposium on Advanced Topics in Electrical Engineering), pp. 1 - 4, Bucharest , 12-14 May 2011.

[4]. F. Bizzarri, A. Brambilla, G. Gruosso, C. Guardiani, A.S. Vincentelli, G.S. Gajani, «Modeling and estimating yield and efficiency of photovoltaic solar parks », in the proceeding of 2013 IEEE ICIT (International Conference on Industrial Technology), pp. 734 - 739, Cape Town, 25-28 Feb. 2013.

[5]. K. Ardani, G. Barbose, R. Margolis, D. Feldman, « Quantifying non-hardware balance of system costs for photovoltaic installations in the United States using a combined annual expenditure-labor hour productivity approach », in the proceeding of 2012 IEEE PVSC ( $38^{\text {th }}$ Photovoltaic Specialists Conference), pp. 001762 - 001767, Austin, TX, 3-8 June 2012.

[6]. M. Aigner, E. Schmautzer, C. Sigl, «Fault loop impedance determination in low-voltage distribution systems with non-linear sources ", in Proceedings of the 2013 IEEE ISGT EUROPE $\left(4^{\text {th }}\right.$
Innovative Smart Grid Technologies Europe), pp. 1 - 5, Lyngby, 6-9 Oct. 2013.

[7]. L. Fanucci, G. Pasetti, P. D'Abramo, R. Serventi, F. Tinfena, P. Chassard, L. Labiste, P. Tisserand, «An high voltage CMOS voltage regulator for automotive alternators with programmable functionalities and full reverse polarity capability ", in Proceedings of the 2010 IEEE DATE (Design, Automation \& Test in Europe Conference \& Exhibition), pp. 526 - 531, Dresden, 812 March 2010.

[8]. W. Xiao, F.F. Edwin, G. Spagnuolo, J. Jatskevich, « Efficient Approaches for Modeling and Simulating Photovoltaic Power Systems », IEEE Journal of Photovoltaics, Vol. 3, Issue. 1, pp. $500-508$, Jan. 2013.

[9]. Y. Mahmoud, W. Xiao, H.H. Zeineldin, « A Simple Approach to Modeling and Simulation of Photovoltaic Modules », IEEE Transactions on Sustainable Energy, Vol. 3, Issue. 1, pp. 185 186, Jan. 2012.

[10]. K. Touafek, M. Haddadi, A. Malek, « Modeling and Experimental Validation of a New Hybrid Photovoltaic Thermal Collector », IEEE Transactions on Energy Conversion, Vol. 26, Issue: 1, pp. 176 - 183, March 2011.

[11]. S. Eidelloth, F. Haase, R. Brendel, «Simulation Tool for Equivalent Circuit Modeling of Photovoltaic Devices », IEEE Journal of Photovoltaics, Vol. 2, Issue. 4, pp. 572 - 579, Oct. 2012.

[12]. F. Adamo, F. Attivissimo, A.D. Nisio, M. Spadavecchia, "Characterization and Testing of a Tool for Photovoltaic Panel Modeling ", IEEE Transactions on Instrumentation and Measurement, Vol. 60, Issue. 5, pp. 1613 - 1622, May 2011.

[13]. P.P. Dash, M. Kazerani, «Dynamic Modeling and Performance Analysis of a Grid-Connected Current-Source Inverter-Based Photovoltaic System », IEEE Transactions on Sustainable Energy, Vol. 2, Issue. 4, pp. 443 - 450, Oct. 2011.

[14]. L. Cristaldi, M. Faifer, M. Rossi, F. Ponci, «A Simple Photovoltaic Panel Model: Characterization Procedure and Evaluation of the Role of Environmental Measurements », IEEE Transactions on Instrumentation and Measurement, Vol. 61, Issue. 10, pp. 2632 - 2641, Oct. 2012.

[15]. A. Chatterjee, A. Keyhani, D. Kapoor, «Identification of Photovoltaic Source Models », IEEE Transactions on Energy Conversion, Vol. 26, Issue. 3, pp. 883 - 889, Sept. 2011.

[16]. M. Hejri, H. Mokhtari, M.R. Azizian, M. Ghandhari, L. Soder, «On the Parameter Extraction of a Five-Parameter Double-Diode Model of Photovoltaic Cells and Modules », IEEE Journal of Photovoltaics, Vol. 4, Issue. 3, pp. 915 - 923, May 2014.

[17]. W. Rezgui, L. H. Mouss, M. D. Mouss, O. KADRI and A. DISSA, "Electrical faults detection for the intelligent diagnosis of a photovoltaic generator », Journal of Electrical Engineering, Vol. 14, Issue. 1, pp. 77-84, March 2014.

[18]. W. Rezgui, L.H. Mouss, N.K. Mouss, M.D. Mouss and M.E.H. Benbouzid, «A smart algorithm for the diagnosis of short-circuit faults in a photovoltaic generator », in Proceedings of the 2014 IEEE ICGE, Sfax (Tunisia), pp. 1-5, March 2014.

[19]. W. Rezgui, L.H. Mouss, N.K. Mouss, M.D. Mouss and M.E.H. Benbouzid, "A Regression Algorithm for the Smart Prognosis of a Reversed Polarity Fault in a Photovoltaic Generator ", in Proceedings of the 2014 IEEE ICGE, Sfax (Tunisia), pp. 1-5, March 2014. 